Beresford, N.A.; Horemans, N.; Copplestone, D.; Raines, K.E.; Orizaola, G.; Wood, M.D.; Laanen, P.; Whitehead, H.C.; Burrows, J.E.; Tinsley, M.C.; Smith, J.T.; Bonzom, J.-M.; Gagnaire, B.; Adam-Guillermin, C.; Gashchak, S.; Jha, A.N.; de Menezes, A.; Willey, N.; Spurgeon, D. 2020. Towards solving a scientific controversy - the effects of ionising radiation on the environment.

(C) 2019 Elsevier Ltd.

This manuscript version is made available under the CC BY-NC-ND 4.0 license http://creativecommons.org/licenses/by-nc-nd/4.0/ (cc) EY-NC-ND

This version available at http://nora.nerc.ac.uk/id/eprint/524855/

Copyright and other rights for material on this site are retained by the rights owners. Users should read the terms and conditions of use of this material at http://nora.nerc.ac.uk/policies.html\#access

This is an unedited manuscript accepted for publication. There may be differences between this and the publisher's version. You are advised to consult the publisher's version if you wish to cite from this article. The definitive version was published in Journal of Environmental Radioactivity (2020), 211. 106033.

https://doi.org/10.1016/i.jenvrad.2019.106033

The definitive version is available at www.elsevier.com/ 


\section{Towards solving a scientific controversy - the effects of ionising radiation on the environment}

N.A. Beresford ${ }^{1,5+}$, N. Horemans ${ }^{2}$, D. Copplestone ${ }^{3}$, K.E. Raines ${ }^{3}$, G. Orizaola ${ }^{4}$, M.D. Wood ${ }^{5}$, P. Laanen ${ }^{2,6}$, H.C. Whitehead ${ }^{5}$, J.E. Burrows ${ }^{3}$, M.C. Tinsley ${ }^{3}$, J.T. Smith ${ }^{7}$, J-M. Bonzom ${ }^{8}$, B. Gagnaire $^{8}$, C. Adam-Guillermin ${ }^{8}$, S. Gashchak ${ }^{9}$, A.N. Jha ${ }^{10}$, A. de Menezes ${ }^{11}$, N. Willey ${ }^{12}$, D. Spurgeon ${ }^{13}$

${ }^{1}$ Centre for Ecology and Hydrology, CEH Lancaster, Lancaster Environment Centre, Library Av., Bailrigg, Lancaster, LA1 4AP, United Kingdom; ${ }^{2}$ Belgian Nuclear Research Centre (SCK•CEN), Boeretang 200, $2400 \mathrm{Mol}$, Belgium; ${ }^{3}$ Faculty of Natural Sciences, University of Stirling, Stirling, FK9 4LA, United Kingdom; ${ }^{4}$ Universidad de Oviedo - Campus de Mieres, Edificio de Investigación 5a planta, c/ Gonzalo Gutiérrez Quirós s/n, 33600 MieresAsturias, Spain; ${ }^{5}$ School of Science, Engineering and Environment, University of Salford, Manchester M5 4WT, United Kingdom; ${ }^{6}$ University of Hasselt, Martelarenlaan 42, 3500 Hasselt, Belgium; ${ }^{7}$ School of Earth and Environmental Sciences, University of Portsmouth, Portsmouth, PO1 3QL, United Kingdom; ${ }^{8}$ IRSN, Centre de Cadarache - 13115 St Paul Lez Durance, France; ${ }^{9}$ Chornobyl Centre for Nuclear Safety, Radioactive Waste and Radioecology, International Radioecology Laboratory, 77th Gvardiiska Dyviiya Str.11, P.O. Box 151, 07100 Slavutych, Kiev Region, Ukraine; ${ }^{10}$ School of Biological and Marine Sciences, University of Plymouth, Plymouth, PL4 8AA, United Kingdom; ${ }^{11}$ Ryan Institute, School of Natural Sciences, National University of Ireland Galway, Ireland; ${ }^{12}$ Centre for Research in Bioscience, Dept. of Applied Sciences, University of the West of England, Frenchay, BS16 1QY, Bristol; ${ }^{13}$ Centre for Ecology and Hydrology, Wallingford, Oxfordshire, OX10 8BB, United Kingdom

${ }^{+}$Corresponding author: nab@ceh.ac.uk

\section{Background}

Human use of radioactivity is increasing in fields such as nuclear power generation and nuclear medicine. Nuclear power continues to be a part of many countries' energy portfolios and may increase dramatically in some Asian countries and Russia, with up to 300 new reactors are currently proposed; other countries without existing nuclear power programmes are beginning to develop them (e.g. some African nations and Persian Gulf states).

Worldwide there are $c .450$ operating nuclear power plants (NPPs) and 60 under construction (World Nuclear Association, 2019). The continued use of nuclear power is considered, by some, as essential in the transition to low-carbon economies (e.g. Liu et al., 2013; Gibon et al., 2017). At the same time, many nations face having to develop long-term strategies, and consequent infrastructure, to manage high-level radioactive waste (as arising from nuclear power production); other nations are challenged with legacy issues associated with, for instance, large-scale accidental releases or past and on-going uranium mining/processing industries.

However, 'nuclear' is not the only source of radionuclides released to the environment. Medical applications of ionising radiation represent the greatest man-made source of ionising radiation exposure to the public (Hoeschen, 2018). Whilst the focus for medical radiation protection research is understandably on protection of workers and patients, the medical uses of radioisotopes result in releases of, often poorly studied, radionuclides to the 
environment. To ensure the safe operation of nuclear, medical and other facilities using radiation we need excellent and robust science on which we can base dose assessments. Issues around nuclear power and radiation have a high media profile often resulting in public concerns over safety and environmental impact.

The system for the protection of humans from ionising radiation is relatively well-developed (ICRP, 2007). However, since c.2000, the International Commission on Radiological Protection's (ICRP) radiation protection framework has required demonstration of the protection of the environment (or wildlife) from radioactive releases (ICRP, 2007). Many countries are now conducting assessments of the potential impact of radioactive releases on the environment (e.g. see Brown et al., 2016). Whilst there has been rapid development of appropriate radiological environmental impact assessment tools (e.g. Beresford et al., 2008a), the supporting science is still developing. Furthermore, there is considerable scientific disagreement on the extent of the impacts of radiation on wildlife in areas of Ukraine/Belarus and Japan contaminated by the Chernobyl and Fukushima reactor accidents respectively (e.g. Beresford et al., 2016a, 2019a; Chesser and Baker, 2006; Mousseau and Møller, 2011; Smith, 2019). Many studies have reported no substantial effects of radiation on wildlife in the Chernobyl Exclusion Zone (CEZ) (e.g. Chesser and Baker, 2006; Deryabina et al., 2015; Murphy et al., 2011; Bonzom et al., 2016). Conversely, others report significant impacts of radiation on wildlife at extremely low dose rates. For instance, significant reductions in invertebrate numbers over dose rates which are in the typical range for natural background exposures (Møller and Mousseau, 2009), LD 50 values (the lethal dose required to kill $50 \%$ of exposed individuals) for butterfly larvae (Hiyama et al., 2012) below the commonly used generic 'predicted no effect dose rate' of $10 \mu \mathrm{Gy} \mathrm{h}^{-1}$ (Andersson et al., 2009; see discussion in Copplestone and Beresford, 2014) and 'significant radiation effects' on bank vole populations at ambient dose rates of $1 \mu \mathrm{Sv} \mathrm{h}{ }^{-1}$ or less (Mappes et al., 2019). If such studies have been correctly conducted and interpreted, then the results would have implications for the system of radiation protection for both the environment and humans (Beresford and Copplestone, 2011).

Many factors may contribute to the reported observations of effects at extremely low dose rates including: lack of consideration of internal exposure; failure to account properly for important (and in many instances) known confounding factors; residual influence of historic acute/high exposure (i.e. there may be effects but are these the consequence of previous high exposures rather than current comparatively low dose rates); incorrect interpretation of statistical results (e.g. a statistically significant correlation does not necessarily imply causation, especially if it explains little of the observed variation) (Gaschak, 2016; BeaugelinSeiller et al., 2019; Beresford et al., 2019a).

The scientific disagreement on the impacts of radiation in the areas affected by the Chernobyl and Fukushima accidents has a relatively high profile in the media (a search using the keyword 'Chernobyl' on https://www.bbc.co.uk/news will adequately demonstrate this); it has also been used to challenge international bodies/national regulators (e.g. https://bit.ly/2yyxehu). Reports of effects at low exposure rates also have the potential to psychologically impact on human populations living in/near 'contaminated' areas. The disagreement amongst radiation effects studies is undoubtedly radioecology's greatest controversy, and it must be addressed through robust and openly reported scientific research, including open sharing of expertise, open exchange of data sets and independent study replication.

This statement paper focusses on research needs with respect to the effects of ionising radiation on the environment (identified needs for human focussed radiological protection 
research can be found elsewhere (Février et al., 2014; Salomaa, 2016; ICRP, 2017)). We emphasise the potential for learning from natural laboratories (namely field sites contaminated by the Chernobyl and Fukushima accidents), taking into account advances from recent co-ordinated research programmes TREE (https://tree.ceh.ac.uk/) and STAR-COMET ${ }^{1}$ (https://radioecology-exchange.org/).

International and national organisations have previously made recommendations on radiological research priorities in order to improve our knowledge on the effects of radiation on wildlife and on ecosystem processes (e.g. primary production, carbon cycling, nutrient dynamics, water cycling, etc.), and to better define environmental radiological assessment approaches (Février et al., 2014; Garnier-Laplace et al., 2018; Pentreath, 2009; ICRP, 2017). These previous recommendations can be broadly summarised as:

1. Improve the estimate of exposure through the development of less uncertain transfer and dosimetry models.

2. Investigate, and subsequently understand, dose-response relationships through studies under both laboratory and contaminated natural conditions (with the recommendation to make better use of contaminated areas, such as the Chernobyl Exclusion Zone (CEZ), to test hypotheses and models).

3. Provide data on radiation effects for key organisms (e.g. those providing the basis for the Reference Animals and Plants (RAPs) within the ICRPs proposed framework for the environment (ICRP, 2009)) for which data are deficient or totally lacking.

4. Determine if there are differences between organisms in radiosensitivity (for similar endpoints) and establish the mechanisms for these differences.

5. Understand how radiation effects combine in a broader ecological context at higher levels of biological organisation (population dynamics, trophic interactions, indirect effects at the community level, and consequences for ecosystem functioning).

6. Investigate how other stressors influence the response to radiation.

7. Identify the prevalence and effects on sensitivity of any potential mechanisms underlying different multi-generational responses to long-term ecologically relevant exposures.

8. Develop relevant biomarkers for monitoring and evaluating effect levels that are explicitly linked to known mechanisms through which radiation exposures affect species.

9. Ensure that new capacity is both developed and maintained recognising the skills shortage in radiation protection and radioecology.

The STAR-COMET and TREE programmes were large multi-institute programmes, in part designed to address these identified priorities. An overview of their contributions to answering the scientific questions is given below.

\section{Overview of recent activities}

The CEZ was proposed by the European radioecological community as a 'radioecological observatory' (or natural laboratory) (Steiner et al., 2013), in part because contamination rates in some areas are such that we may anticipate observing radiation effects in wild organisms. Radioecological observatories are contaminated field sites that could provide a co-ordinated

${ }^{1}$ The COMET project took forward activities initiated by the STAR project. 
focus for long-term joint field investigations (Muikku et al., 2018). The TREE and COMET projects collaborated, establishing wider networks to extend the scope of their individual research and using common field sites within the CEZ. This productive collaboration demonstrated that the 'radioecological observatories' concept can be successful. Together, the TREE and COMET projects represent the largest co-ordinated study of the effects of radiation on wildlife conducted in the $\mathrm{CEZ}$, with research considering a range of freshwater and terrestrial species, from plants to mammals.

The COMET and TREE projects have only recently finished and results are still being published (see https://tree.ceh.ac.uk/content/tree-publications-and-datasets, https://radioecology-exchange.org/content/star-publications and https://radioecologyexchange.org/ for publications to date. However, the time is now appropriate to review the progress made by these projects against the previously identified priorities, and to highlight remaining research needs and the new questions raised.

\subsection{Exposure}

A criticism of many studies reporting effects on wildlife in the CEZ is that the estimation of exposure is poor (Beaugelin-Seiller et al., 2019; Beresford et al., 2019a). Many studies relate observations simply to dose rate readings from handheld dosimeters, with no consideration of internal exposure or the mobility of many organisms in extremely heterogeneously contaminated environments (e.g. Møller and Mousseau, 2009, 2013; Lehmann et al., 2016).

The estimation of radionuclide transfer to wildlife, and hence internal dose, is acknowledged to be a major uncertainty in environmental assessment (e.g. IAEA 2014; Beresford et al., 2008a). Most assessment models use a simple concentration ratio (CR) relating the activity concentration in an organism to that in the relevant media (typically soil and water for terrestrial and aquatic organisms respectively (IAEA, 2014)). Concentration ratios are highly variable, with ranges over four orders of magnitude being common for a given organismradionuclide combination (IAEA, 2014); site-specific factors (e.g. soil or water chemistry) being a major contributor to this variation. Furthermore, data are lacking for many organisms and/or radionuclides.

The TREE and COMET projects collaborated in establishing an alternative approach based on taxonomic groupings (Beresford et al., 2013). This approach (i) gives a method of prediction which takes account of the effect of site, and (ii) offers an extrapolation methodology to provide predictions of activity concentrations for organisms for which data are lacking. The validations undertaken to date have shown the resultant transfer predictions to be closer to measured values than those obtained using the $\mathrm{CR}$ approach for Cs and freshwater fish (Beresford et al., 2013, 2016b), and Sr, Cs, U, Pb and Se for terrestrial species (Søvik et al., 2017; Beresford and Willey, 2019). However, whilst it was possible to apply this approach to the available data for marine species for Cs, validation against blind test datasets for a range of marine species revealed poor predictions (Brown et al., 2019); further work is required to determine the applicability of this approach to marine ecosystems.

Measuring activity concentrations in organisms is preferable to having to predict them. However, in many situations, it is undesirable to euthanize animals for laboratory analyses. Live-monitoring techniques have been widely used to determine the activity concentrations of gamma-emitting radionuclides such as ${ }^{134,137} \mathrm{Cs}$ and ${ }^{131} \mathrm{I}$ in live animals (e.g. Meredith et 
al., 1988; Brynildsen and Strand, 1994; Moss and Horrill, 1996; Beresford et al., 1997). However, in the CEZ (or other contaminated sites) radionuclides other than gamma-emitters may contribute significantly to dose. To address this, a detector capable of measuring gamma-emitters and ${ }^{90} \mathrm{Sr}$ has been developed and applied in the CEZ (Fawkes, 2018); unlike previous detectors capable of simultaneous gamma and beta measurements (Bondarkov et al., 2011), this new detector is fully portable making it suitable for use in the field.

Few studies have considered the validation of external dose rates predicted by assessment models (to our knowledge only Beresford et al., (2008b) have previously attempted to do this). Aramrun et al., 2018 evaluated different dosimeters that could be attached to free ranging animals and discussed their field application. A subsequent field study with reindeer

(Rangifer tarandus tarandus) demonstrated that using knowledge of animal behaviour (in this case determined using GPS tracking) resulted in better predictions than simply assuming that the animals utilised all of the study area equally (Aramrun et al., 2019). Hinton et al., (2015) describe the development of a combined Global Positioning System - electronic dosimeter capable of sending location and integrated dose measurements via satellite whilst fitted to study animals (the unit was successfully field-tested by mounting on a collar and fitting to wild pigs at the Savannah River Site (USA)).

\subsection{Effects}

Key to the work plans of many of the effect studies was the combination of field and laboratory studies using the same organisms (e.g. Goodman, 2019; Raines, 2018), which enabled tests of whether effects observed in the field were due to radiation rather than other known or potentially unmeasured covariates.

\subsubsection{Key organisms}

New radiation effects data were produced for previously poorly studied organisms. For example, invertebrates comprised less than $7 \%$ of low-dose radiation effects studies in the FREDERICA radiation effects database (Copplestone et al., 2008); the recent studies have considered a range of invertebrates including earthworms, bees, Daphnia pulex, Asellus aquaticus and Caenorhabditis elegans. In some cases, the species selected for study within the COMET and TREE projects were chosen as they aligned with the definition of the RAPs that are being used within the developing ICRP framework for radiological protection of the environment (ICRP, 2009). Data obtained from studies on these species will be of value to develop further the ICRP system (ICRP, 2017). Organisms representative of the RAPs which were studied included, bees (Raines, 2018), earthworms (Newbold et al., submitted), frogs (Giraudeau et al., 2018; Gombeau et al., submitted) and pine trees (Volkova et al., 2018). In the case of bees, there were previously no effects data available (ICRP, 2009). By studying bumblebees, the TREE project has provided the first data to inform on the placement of derived consideration reference levels (DCRLs) for the ICRP RAP Bee (DCRLs are defined as "a band of dose rate within which there is likely to be some chance of deleterious effects of ionising radiation occurring to individuals of that type of RAP" (ICRP, 2009)).

Recognising the general lack of transgenerational and multigenerational studies and their potential importance in understanding the impacts of long-term exposure in radiologically contaminated environments, some studies focussed on model organisms with well-defined genomes allowing complex genetic/epigenetic analyses. Species studied included 
Arabidopsis thaliana (Horemans et al., 2018; van de Walle et al., 2016; Caplin and Willey, 2018), Daphnia pulex (Goodman, 2019; Parisot et al., 2015), Danio rerio (Gombeau et al., 2017) and Caenorhabditis elegans (Dutilleul et al., 2015). In addition to existing in-depth knowledge of their genome, the short generation times and relative ease of culturing and maintaining these species was critical to their selection for these challenging long-term effect assessment studies which by their nature involve assessment of effects over parental and subsequent generations.

As an example, several reproductive parameters were measured in a range of freshwater organisms from the CEZ. No significant alterations to reproductive fitness were detected in the crustaceans Asellus aquaticus (Fuller et al., 2018) and Daphnia pulex (Goodman et al., 2019). Whilst fish species (Rutilus rutilus and Perca fluviatilis) were found to in generally good reproductive health, a delay in the maturation of the gonads was evident for $P$.

fluviatilis in the most contaminated lakes (this was not observed for $R$. rutilus) (Lerebours et al., 2018).

Some of the studied species were present in both the Fukushima Exclusion Zone (FEZ) and the CEZ, enabling some studies to be conducted on the same/similar species at the two sites (e.g. for Brassicaceae, Horemans et al., 2018). Many of the species also allowed comparative field and controlled laboratory studies.

\subsubsection{An epigenetic or genetic response to ionising radiation?}

Prior to the COMET and TREE projects, the Radioecology Strategic Research Agenda (SRA) (Février et al., 2014) identified the need to "mechanistically understand how processes link radiation induced effects in wildlife from molecular to individual levels of biological complexity". A mechanistic understanding of how organisms respond to radiation will help us to establish why species respond differently to radiation exposure. Consequently, several studies examined epigenetic and genetic changes in response to radiation exposure in different species.

Among the species studied changes in DNA methylation status were frequently observed in response to radiation, with hypermethylation being the most common. For example, the absorbed total dose rate was estimated together with mitochondrial DNA damage and DNA methylation for tree frogs sampled in Fukushima (Gombeau et al., submitted). Frogs from contaminated sites exhibited a dose dependent increase of global genomic DNA methylation level and of mitochondrial DNA damage. This result potentially suggests that DNA methylation is involved in genomic instability, possibly providing a favorable ability to organisms to adapt to stressful environmental conditions.

However, DNA methylation response differed between species, cell types, tissues, and with age. For plants, species and location dependent differences were found in the three studied species. In Arabidopsis thaliana sampled from the CEZ, genome-wide methylation decreased in response to increasing radiation dose rates (Horemans et al., 2018). Contrastingly, in the FEZ, there was no alteration to genome-wide methylation of another member of the same taxonimic (Brassicaceae) family, Capsella bursa-pastoris (Horemans et al., 2018). Amplified fragment length polymorphisms (AFLPs) measured in Scots Pine exposed to contamination after the Chernobly accident revealed hyper-methylation of the irradiated pine genomes, but this was not associated with the annual dose received (Volkova et al., 2018). Using the same 
AFLP techniques to study of DNA methylation in earthworms, however, did not lead to a measurable link between internal dose rate and DNA methylation status (Newbold et al., submitted).

Furthermore, for field observations there are potential confounding environmental and climatic variables that can affect DNA methylation status, potentially resulting in variability between samples and causing between site differences that are not linked due to radiation exposure. Hence, careful consideration of species specific and environmental information is needed for interpreting results on global DNA methylation. In some studies additional endpoints like levels of DNA damage or induction of DNA repair mechanisms or reactive oxygen species scavenging enzymes have been shown to concomitantly occur with changes in epigenetic marks, however, so far little evidence is available to mechanistically link these changes (Horemans et al., 2019).

A major conclusion of these studies was that global methylation alone may be too general a measure of epigenetic changes to see all biologically relevant differences induced by exposure to low dose rates and that more in depth (epi)genetic studies are needed (Horemans et al., 2019).

\subsubsection{The CEZ as a multi-stressor environment?}

It has previously been speculated that the CEZ may contain areas with high concentrations of some non-radioactive pollutants (with the implication that these may contribute to any observed effects). This speculation resulted from knowledge of materials used in 1986 by fire fighters in response to the Chernobyl accident (e.g. $2500 \mathrm{t}$ of $\mathrm{Pb}$ were dropped onto the burning reactor (National Report of Ukraine, 2011)). However, a study conducted on a terrestrial site in the Red Forest, found levels of $\mathrm{Pb}$ in soil typical for European soils (Beresford et al., 2019b), which agrees with Jagoe et al., (1998) who found no elevated Pb (or $\mathrm{Hg}$ ) concentrations in freshwater ecosystems close to the Chernobyl NPP. Hence, based on current evidence, it seems unlikely that there is widespread non-radiological contamination in the CEZ because of the accident. However, it is conceivable that due to industrial activities pre-1986, some areas of the CEZ may be polluted with historical non-radiological contaminants (Sharov et al., 2016).

However, even in the absence of significant point-source or diffuse non-radiological pollution, organisms within the CEZ are likely exposed to a range of other stressors that are potentially influencing reported relationships between exposure and 'effect'. For instance, the predominant soil in much of the CEZ, including the most contaminated areas, is sandy with implications for some species (e.g. such soil conditions are not favourable for earthworms (Newbold et al., submitted)). Similarly, habitat quality is poor in the more contaminated areas (Gaschak, 2016; Beresford et al., 2019a) and large areas of the Red Forest (Earth's most radiologically contaminated terrestrial ecosystem) are prone to spring flooding. Human disturbance in the vicinity of the Red Forest is also relatively high due to proximity to the nuclear power complex and access roads. In July 2016, the Red Forest suffered a widespread fire affecting about $80 \%$ of its area. This presented a unique opportunity for studying the interaction between radiation and an additional stressor (fire) on ecosystem recovery (see https://www.ceh.ac.uk/redfire for details).

\section{Future research questions}


There has been an assumption that extending/adapting the radiological protection framework for humans will suffice for protecting the environment. However, whilst frameworks for the environment and humans will be able to contain many similar elements there are important differences. The effects of radiation on the environment, or wildlife, remains an area of considerable scientific disagreement with a high public profile. Recent studies, as outlined above, have significantly advanced our understanding of species-level radiation effects for a limited range of test organisms. A step change in research is required to improve understanding of the effects of radiation on wildlife. In our view, future research should focus on answering the following questions:

- What are the key factors determining interspecies vulnerability to radiation? Sensitive species may require special attention for monitoring and radioprotection. We need to develop a fundamental mechanistic understanding of why organisms respond differently to radiation exposure. In this context, we need to understand how the potential susceptibility to relevant molecular initiating events that trigger, for instance, critical pathways like DNA or oxidative damage, vary between species and how protective mechanisms (e.g. DNA repair mechanisms or induction of antioxidative mechansims) in those species may attenuate such effects. This will help to define robust benchmark doses that are protective of all species. This is especially required as some recent research suggests that current international protection benchmarks may not be protective of all organism groups (Raines, 2018). Differences in sensitivity between species also lie behind overall effects at higher levels (community, ecosystem), since interactions between species will be altered. Understanding the mechanisms of inter-species radiation sensitivity may also help us understand mechanisms behind intra-species variation.

- What are the combined ecological effects of changes in developmental/reproductive endpoints of different species within an ecosystem? The aim of environmental protection is generally to protect populations/communities. However, our knowledge is founded on responses of individuals to radiation exposure. Recent studies (ALLIANCE, 2018) demonstrate shifts in developmental and reproductive endpoints (e.g. flowering time or sexual maturity) due to radiation exposure. Although these shifts may appear minor when considered in isolation, their combined ecological effects may be significant (e.g., delayed production of pollinators and earlier flowering may mean no floral resources are available for pollinators). Here there is potential to learn from work done in the area of phenology in climate research in which researchers have sought to understand how species life-cycle dynamics may become uncoupled from the resources (e.g. food supply, nest sites, pollinators) on which they rely (Thackeray et al., 2016). Addressing this question would enable an evaluation of the potential impact of radiation on ecosystem function and the provision of goods and services provided by the environment of importance to humans; the consequences of increased ionising radiation levels on key ecosystem processes has previously received little attention.

- What is the impact of previous 'acute' radiation exposure on organisms in contaminated environments now? There are a number of studies reporting significant impacts of radiation on wildlife in the CEZ at relatively low dose rates (e.g. Aguileta et al., 2016; Bezrukov et al., 2015; Møller and Mousseau, 2009, 2013, 2018; Morelli et al., 2018). However, in these studies, the effects of radiation on CEZ wildlife are 
often related to current, comparatively low, exposure levels. We hypothesise that such observations may, in part, result from acute historic exposures (Beresford, et al., 2019a). For example, ecological changes in community structure may result in communities entering different stable states from which return to the original condition is impaired. Further, when chemicals interact with the epigenome there is increasing evidence that this can lead to heritable changes in properties such as DNA methylation status, histones and even microRNA expression that can result in modified physiological states in direct progeny (and even later) generations (Horemans et al., 2019). For radiation, we can (probably uniquely for a pollutant) reconstruct past exposures with some confidence. Consequently, it should be possible to test our hypothesis by combining field and laboratory studies with retrospective dose assessment.

- What are the interactions between radiation and other stressors (both natural and anthropogenic)? Ecotoxicology has been trying to answer the question of multicontaminant/stressors for some years (Gilbin et al., 2015; Gagnaire et al., 2017). Radioactivity rarely occurs in isolation from other contaminants as well as abiotic and biotic stressors (e.g. soil and water chemical status, climate, pathogens/parasites etc.), and we have little knowledge of their combined effects. To be able to assess the suitability of current regulations in a multi-contaminant/stressor environment, we need to address this lack of knowledge. While studies of stressor interactions are common in ecotoxicology, it has been difficult to derive general rules by which to predict how different species may be effected by a given combined stressor exposure (additive, greater than additive, less than additive) (Holmstrup et al., 2010). For many species, the limits of tolerance for some types of stressors (e.g. soil $\mathrm{pH}$, temperature ranges) are known. Measurements of potential stressors along with radioecological measurements may identify those cases in which radionuclide exposures coincide with other stressful conditions helping to identify when multiple stressor effects may need to be taken in to account.

- Can biomarkers provide non-lethal characterisation of stressor impacts? There remains continued interest in the use of biomarkers for non-lethal characterisation of exposure and impact. Radiation-specific biomarkers for environmentally relevant dose rates are lacking, but the community opinion is that biomarkers of impact (from multiple stressors) could be developed (Wood et al., submitted). Establishing relationships between non-lethal biomarker response and an effect of environmental protection relevance would provide powerful tools to underpin studies of intra-species variation in exposure response and multiple-stressor impacts. One way of describing the links between molecular initiation of the response and the observed adverse effects is through the formulation of an Adverse Outcome Pathway (AOP). The formulation of a radiation specific AOP will form a framework within which data and knowledge coming from different organisms, different levels of biological complexity and even multiple stressors are synthesised in a way that is useful for risk assessment (Ankley et al., 2010); the key molecular events (which may include epigenetic change) of an AOP might serve as a potential biomarker. A radiation-related AOP for different organisms together with specific biomarkers could potentially be used in a regulatory setting to verify the results of impact assessments for operational facilities. 
- Do organisms living in a radiologically contaminated environment become adapted to radiation across multiple generations? Populations living in ecosystems where they are chronically exposed to stressors, including pollutants, may become adapted to these conditions through phenotypic plasticity and natural selection. The mechanisms involved in organism responses to chronic radiation exposure, both within and between generations, are the subject of an active debate in the scientific literature (e.g. Boubriak et al., 2016; Carroll et al., 2007; Goodman et al., 2019; Horemans et al., 2019). Whilst adaptation of organisms to radiation within the CEZ has been suggested (Møller and Mousseau, 2016; Boubriak et al., 2008), it has not yet been the focus of any comprehensive research programme. If it does occur, adaptation of specific populations could lead to adaptation of the ecosystem over time (e.g. the plant biome is thought to help plants cope with abiotic stress such as drought or salinity (Dodd and Pérez-Alfocea, 2012; Liu and Zhang, 2015)). If adaptation to chronic radiation exposure exists in the CEZ, it will have implications for the interpretation of studies comparing current effect and exposure levels.

- What are the effects of radiation on ecosystem functioning? Studies have investigated the effects of ionising radiation on wildlife from subcellular to community levels in the CEZ (e.g. Beresford et al., 2019a) and increasingly in the Fukushima region. However, the consequences of increased ionising radiation levels on key ecosystem processes such as plant production, the degradation of dead organic matter, and elemental cycling have received little attention.

The Chernobyl and Fukushima Exclusion Zones, and indeed other contaminated sites such as Kyshtym (Fesenko, 2019), present large natural laboratories with spatially varying contamination levels. These locations provide an opportunity to conduct studies that help address the above questions. To help address the lack of scientific consensus with respect to the effects of radiation in contaminated environments, future studies should set out to address hypotheses raised in papers reporting significant effects at, in many instances, extremely low dose rates. Where feasible, future research should combine studies at contaminated field sites with controlled laboratory exposures of the same/similar organisms. Fukushima currently offers a useful comparator to Chernobyl, as it is a site more recently contaminated. To date, there have been no co-ordinated international research programmes focused on environmental effects in the Fukushima contaminated areas of Japan; to best exploit the unique scientific opportunity that Fukushima presents, the international community needs to act quickly before too much time passes.

We reiterate the recommendation in Barnett and Welch (2016) that the underpinning data from radiation effects studies should be openly and freely available. Making all of the data from radioecological studies openly available would represent a significant step towards understanding the disagreement on the magnitude of effects due to exposure to ionising radiation observed in both the CEZ and Fukushima areas by enabling independent reevaluation. To this end, we have begun to openly publish all of the underlying data from our studies in the CEZ (see https://tree.ceh.ac.uk/content/tree-publications-and-datasets). Making data available is now a requirement of many journals and funders, but unfortunately it is a practice which is not rigorously followed. This situation needs to improve and the help of journals and funders is needed to ensure this, otherwise the impasse of not sharing data will not be resolved. 
The COMET and TREE projects have demonstrated the value of multinational and multidisciplinary projects in beginning to address the questions that are posed by relatively highly contaminated environments such as the CEZ and FEZ. The contributions of the projects to radioecology have been independently recognised (Thorne, 2018) and we recommend that to address the research questions highlighted above similar co-ordinated multidisciplinary programmes are required.

\section{Acknowledgements}

This statement paper originates following discussions held in March 2019 (https://www.ceh.ac.uk/news-and-media/blogs/what-are-effects-radiation-wildlife-discussingresults-chernobyl) between the TREE project participants and members of the European Radioecology ALLIANCE working group on 'transgenerational effects and species radiosensitivity' (https://radioecology-

exchange.org/sites/default/files/T1_WG_for\%20Radioecology\%20Roadmap_Effects_Jan\%2 02015.pdf).

The TREE project (www.ceh.ac.uk/TREE) was funded by the Natural Environment Research Council, the Environment Agency and Radioactive Waste Management Ltd. Both the STAR (ID: 269672) and COMET (ID: 60497) projects (https://radioecology-exchange.org/) were supported by the EC EURATOM programme and respective national funders.

Thanks go to Cath Barnett (CEH Lancaster) for help in preparing this article, and to Louise Paul and Claire Cailes (Environment Agency) for comments on the draft manuscript.

\section{References}

Aguileta, G., Badouin, H., Hood, M.E., Møller, A.P., Le Prieur, S., Snirc, A., Siguenza, S., Mousseau, T.A., Shykoff, J.A., Cuomo, C.A., Giraud, T. 2016. Lower prevalence but similar fitness in a parasitic fungus at higher radiation levels near Chernobyl. Mol. Ecol., 25, 33703383. http://dx.doi.org/10.1111/mec.13675

ALLIANCE. 2018. https://radioecologyexchange.org/sites/default/files/FINAL\%20Report\%20on\%20Paris\%20ALLIANCE\%202018 \%20Workshop\%20on\%20epigenetic.pdf Accessed 15/7/2019

Andersson, P., Garnier-Laplace, J., Beresford, N.A., Copplestone, D., Howard, B.J., Howe, P., Oughton, D., Whitehouse, P. 2009. Protection of the environment from ionising radiation in a regulatory context (PROTECT): proposed numerical benchmark values. J. Environ. Radioact., 100, 1100-1108. http://dx.doi.org/10.1016/j.jenvrad.2009.05.010

Ankley, G.T., Bennett, R.S., Erickson, R.J., Hoff, D.J., Hornung, M.W., Johnson, R.D., Mount, D.R., Nichols, J.W., Russom, C.L., Schmieder, P.K., Serrrano, J.A., Tietge, J.E., Villeneuve, D.L. 2010. Adverse outcome pathways: a conceptual framework to support ecotoxicology research and risk assessment. Environ. Toxicol. Chem., 29,730-741. https://doi.org/10.1002/etc.34

Aramrun, P., Beresford, N.A., Wood, M. 2018. Selecting passive dosimetry technologies for measuring the external dose of terrestrial wildlife. J. Environ. Radioact., 182, 128-137. http://dx.doi.org/10.1016/j.jenvrad.2017.12.001 
Aramrun, K., Beresford, N., Skuterud, L., Hevroy, T., Drefvelin, J., Bennett, K. Yurosko, C., Phruksarojanakun, P., Esoa, J., Yongprawat, M., Siegenthaler, A., Fawkes, R., Tumnoi, W., Wood, M. 2019. Measuring the radiation exposure of Norwegian reindeer under field conditions. Sci. Tot. Environ., 687, 1337-1343.

http://dx.doi.org/10.1016/j.scitotenv.2019.06.177

Barnett, C.L., Welch, S. (Eds.). 2016. Thirty years after the Chernobyl accident: what do we know about the effects of radiation on the environment? Workshop report. COMET D-N5.6. Contract No. Fission-2012-3.4.1-604794. https://radioecology-

exchange.org/sites/default/files/files/Deliverable_56_COMET_workshop_4_final.pdf Accessed 15/7/2019.

Beresford, N.A., Mayes, R.W., Barnett, C.L., Lamb, C.S., Wilson, P.J., Howard, B.J., Voigt G. 1997. The effectiveness of oral administration of potassium iodide to lactating goats in reducing the transfer of radioiodine to milk. J. Environ. Radioact., 35, 115-128. https://doi.org/10.1016/S0265-931X(96)00050-1

Beresford, N.A., Balonov, M., Beaugelin-Seiller, K., Brown, J., Copplestone, D., Hingston, J.L., Horyna, J., Hosseini, A., Howard, B.J., Kamboj, S., Nedveckaite, T., Olyslaegers, G., Sazykina, T., Vives i Batlle, J., Yankovich, T.L., Yu. C. 2008a. An international comparison of models and approaches for the estimation of the radiological exposure of non-human biota. Appl. Radiat. Isot., 66, 1745-1749. http://dx.doi.org/10.1016/j.apradiso.2008.04.009

Beresford, N.A., Gaschak, S., Barnett, C.L., Howard, B.J., Chizhevsky, I., Strømman, G., Oughton, D.H., Wright, S.M., Maksimenko, A., Copplestone D. 2008b. Estimating the exposure of small mammals at three sites within the Chernobyl exclusion zone - a test application of the ERICA Tool. J. Environ. Radioact., 99, 1496-1502.

http://dx.doi.org/10.1016/j.jenvrad.2008.03.002

Beresford, N.A., Copplestone, D. 2011. Effects of ionizing radiation on wildlife: what knowledge have we gained between the Chernobyl and Fukushima accidents? Integer. Environ. Assess. Manag., 7, 371-73. http://dx.doi.org/10.1002/ieam.238

Beresford, N.A., Yankovich, T.L., Wood, M.D., Fesenko, S., Andersson, P., Muikku, M., Willey, N.J. 2013. A new approach to predicting environmental transfer of radionuclides: a demonstration for freshwater fish and caesium. Sci, Tot. Environ., 463-464, 284-292. https://doi.org/10.1016/j.scitotenv.2013.06.013

Beresford, N.A., Fesenko, S., Konoplev, A., Smith, J.T., Skuterud, L., Voigt, G. 2016a. Thirty years after the Chernobyl accident: what lessons have we learnt? J. Environ. Radioact. 157, 77-89. http://dx.doi.org/10.1016/j.jenvrad.2016.02.003

Beresford, N.A., Wood, M.D., Vives i Batlle, J., Yankovich, T.L., Bradshaw, C., Willey, N. 2016b. Making the most of what we have: application of extrapolation approaches in radioecological wildlife transfer models. J. Environ. Radioact. 151, 373-386. http://dx.doi.org/10.1016/j.jenvrad.2015.03.022

Beresford, N.A., Willey, N. 2019. Moving radiation protection on from the limitations of empirical concentration ratios. J. Environ. Radioact., 208-209, 106020. https://doi.org/10.1016/j.jenvrad.2019.106020

Beresford, N.A., Scott, E.M., Copplestone, D. 2019a. Field effects studies in the Chernobyl Exclusion Zone: Lessons to be learnt. J. Environ. Radioact., 105893

https://doi.org/10.1016/j.jenvrad.2019.01.005 
Beresford, N.A., Barnett, C.L., Gashchak, S., Maksimenko, A., Guliaichenko, E., Wood, M.D., Izquierdo, M. 2019b. Radionuclide transfer to wildlife at a 'Reference Site' in the Chernobyl Exclusion Zone and resultant radiation exposures. J. Environ. Radioact., 105661. https://doi.org/10.1016/j.jenvrad.2018.02.007

Beaugelin-Seiller, K., Garnier-Laplace, J., Beresford, N.A. 2019. Estimating radiological exposure of wildlife in the field. J. Environ. Radioact., 105830.

https://doi.org/10.1016/j.jenvrad.2018.10.006

Bezrukov, V., Møller, A.P., Milinevsky, G., Rushkovsky, S., Sobol, M., Mousseau, T.A. 2015. Heterogeneous relationships between abundance of soil surface invertebrates and radiation from Chernobyl. Ecol. Ind., 52, 128-133.

https://doi.org/10.1016/j.ecolind.2014.11.014

Bondarkov, M.D., Maksimenko, A.M., Gaschak, S., Zheltonozhsky, V.A., Jannik, G.T., Farfán, E.B. 2011. Method for simultaneous ${ }^{90} \mathrm{Sr}$ and ${ }^{137} \mathrm{Cs}$ in-vivo measurements of small animals and other environmental media developed for the conditions of the Chernobyl exclusion zone. Hlth. Phys., 101, 383-392. https://doi.org/10.1097/HP.0b013e318224bb2b

Bonzom, J-M., Hattenschwiler, S., Lecomte-Pradines, C., Chauvet, E., Gaschak, S., Beaugelin-Seiller, K., Della-Vedova, C., Dubourg, N., Maksimenko, A., Garnier-Laplace, J., Adam-Guillermin, C. 2016. Effects of radionuclide contamination on leaf litter decomposition in the Chernobyl exclusion zone. Sci. Tot. Environ., 562, 596-603. https://doi.org/10.1016/j.scitotenv.2016.04.006.

Boubriak, I.I., Grodzinsky, D.M., Polischuk, V.P., Naumenko, V.D., Gushcha, N.P., Micheev, A.N., McCready, S.J., Osborne, D.J. 2008. Adaptation and impairment of DNA repair function in pollen of Betula verrucosa and seeds of Oenothera biennis from differently radionuclide-contaminated sites of Chernobyl. Ann. Bot., 101, 267-276.

https://doi.org/10.1093/aob/mcm276

Boubriak, I., Akimkina, T., Polischuk, V., Dmitriev, A., McCready, S., Grodzinsky, D. 2016. Long term effects of Chernobyl contamination on DNA repair function and plant resistance to different biotic and abiotic stress factors. Cytol. Genet., 50, 381-399.

https://doi.org/10.3103/S0095452716060049

Brown, J.E., Alfonso, B., Avila, R., Beresford, N.A., Copplestone, D., Hosseini, A. 2016. A new version of the ERICA Tool to facilitate impact assessments of radioactivity on wild plants and animals. J. Environ. Radioact., 153, 141-148.

http://dx.doi.org/10.1016/j.jenvrad.2015.12.011

Brown, J.E., Beresford, N.A., Hevrøy, T.H. 2019. Exploring taxonomic and phylogenetic relationships to predict radiocaesium transfer to marine biota Sci. Tot. Environ. 649, 916-928. https://doi.org/10.1016/j.scitotenv.2018.08.343

Brynildsen, L.I., Strand, P. 1994. A rapid method for the determination of radioactive caesium in live animals and carcasses, and its practical application in Norway after the Chernobyl nuclear reactor accident. Acta. Vet. Scand., 35, 401-408.

Caplin, N., Willey, N. 2018. Ionizing radiation, higher plants, and radioprotection: from acute high doses to chronic low doses. Front. Plant Sci., 9, 847.

https://doi.org/10.3389/fpls.2018.00847

Carroll, S.P., Hendry A.P., Reznick, D.N., Fox, C.W. 2007. Evolution on ecological timescales. Funct. Ecol., 21, 387-393. https://doi.org/10.1111/j.1365-2435.2007.01289.X 
Chesser, R., Baker, R.J. 2006. Growing up with Chernobyl. American Scientist, 94. https://www.jstor.org/stable/27858869 Accessed 15/7/2019.

Copplestone, D., Beresford, N.A. 2014. Questionable studies won't help identify Fukushima's effects. The Conversation http://theconversation.com/questionable-studies-wont-helpidentify-fukushimas-effects-26772 Accessed 15/7/2019.

Copplestone, D., Hingston, J., Real, A. 2008. The development and purpose of the FREDERICA radiation effects database. J. Environ. Radioact., 99, 1456-1463. https://doi.org/10.1016/j.jenvrad.2008.01.006

Deryabina, T.G., Kuchmel, S.V., Nagorskaya, L.L., Hinton, T.G., Beasley, J.C., Lerebours, A., Smith, J.T. 2015. Long-term census data reveal abundant wildlife populations at Chernobyl. Curr. Biol., 25. R824-R82. https://doi.org/10.1016/j.cub.2015.08.017

Dodd, I.C., Pérez-Alfocea, F. 2012. Microbial amelioration of crop salinity stress. J. Exp. Bot., 63, 3415-3428. https://doi.org/10.1093/jxb/ers033

Dutilleul, M., Goussen, B., Bonzom, J-M., Galas, S., Réale, D. 2015. Pollution breaks down the genetic architecture of life history traits in Caenorhabditis elegans. PLoS ONE, 10, e0116214. https://doi.org/10.1371/journal.pone.0116214

Fawkes, R. 2018. An innovative portable detector for the live-monitoring of radionuclides in small terrestrial animals. PhD thesis. University of Salford.

Fesenko, S. 2019. Review of radiation effects in non-human species in areas affected by the Kyshtym accident. J. Radiol. Prot., 39, R1-R117. https://doi.org/10.1088/1361-6498/aafa92

Février, L., Oughton, D., Hinton, T.G. 2014. Strategic Research Agenda for radioecology an updated version with stakeholder input. D-N ${ }^{\circ}$ 2.5. STAR. Contract Number: Fission-20103.5.1-269672. https://radioecology-

exchange.org/sites/default/files/STAR\%20D2.5\%20Strategic\%20research\%20agendaupdated\%20version.pdf Accessed 15/7/2019.

Fuller, N., Ford, A.T., Nagorskaya, L.L., Gudkov, D.I., Smith, J.T. 2018. Reproduction in the freshwater crustacean Asellus aquaticus along a gradient of radionuclide contamination at Chernobyl. Sci. Tot. Environ., 629, 11-17. https://doi.org/10.1016/j.scitotenv.2018.01.309

Gagnaire, B., Adam-Guillermin, C., Festarini, A., Cavalié, I., Della-Vedova, C., Shultz, C., Kim, S.B., Ikert, H., Dubois, C., Walsh, S., Farrow, F., Beaton, D., Tan, E., Wen, K., Stuart, M. 2017. Effects of in situ exposure to tritiated natural environments: A multi-biomarker approach using the fathead minnow, Pimephales promelas. Sci. Tot. Environ., 599-600, $597-$ 611. https://doi.org/10.1016/j.scitotenv.2017.04.210

Garnier-Laplace, J., Vandenhove, H., Beresford, N., Muikku, M., Real, A. 2018. COMET strongly supported the development and implementation of medium-term topical research roadmaps consistent with the ALLIANCE Strategic Research Agenda. J. Radiol. Prot., 38, 164-174. https://doi.org/10.1088/1361-6498/aa9c0a

Gaschak, S. 2016. Assessment of radiation effects in birds breeding in Red Forest area (20032005): problems of research approaches and interpretation of the results. In: Barnett, C.L., Welch, S. (Eds.), COMET Workshop report: Thirty years after the Chernobyl accident: what do we know about the effects of radiation on the environment? pp. 20-22. COMET D-N 5.6 . Contract No. Fission-2012-3.4.1-604794. https://radioecologyexchange.org/sites/default/files/files/Deliverable_56_COMET_workshop_4_final.pdf Accessed 30/7/2019. 
Gibon, T., Hertwich, E.G., Arvesen, A., Singh, B., Verones, F. 2017. Health benefits, ecological threats of low-carbon electricity. Environ. Res. Lett., 12, 03402.

https://doi.org/10.1088/1748-9326/aa6047

Gilbin, R., Horemans, N., Spurgeon, D., Bradshaw, C., Svendsen, C., Teien, H-C.,

Nascimento, F., Lofts, S., Février, L., Vandenhove, H. 2015. Critical evaluation of robustness of protection levels in a multiple contaminant context. STAR D-N $\mathrm{N}^{\circ}$.4. Contract No. Fission2010-3.5.1-269672. https://radioecology-exchange.org/sites/default/files/D4.4_final.pdf Accessed 15/7/2019.

Giraudeau, M., Bonzom, J-M., Ducatez, S., Beaugelin-Sellier, K., Deviche, P., Lengagne, T., Cavalie, I., Camilleri, V., Adam-Guillermin, C., McGraw, K. 2018. Carotenoid distribution in wild Japanese tree frogs (Hyla japonica) exposed to ionizing radiation in Fukushima. Sci. Rep., 8, 7438. https://doi.org/10.1038/s41598-018-25495-5

Gombeau, K., Bourdineaud, J.P., Ravanat, J.L., Armant, O., Camilleri, V., Cavalie, I., Floriani, M., Adam-Guillermin, C. 2017. Epigenetic, histopathological and transcriptomic effects following exposure to depleted uranium in adult zebrafish and their progeny. Aquat. Toxicol., 184, 14-25. https://doi.org/10.1016/j.aquatox.2016.12.004

Gombeau, K., Bonzom, J-M., Cavalié, I., Camilleri, C., Orjollet, D., Dubourg, N., BeaugelinSeiller, K., Della-Vedova, C., Bourdineaud, J-P., Lengagne, T., Armant, O., Ravanat, J-L., Adam-Guillermin, C. Submitted. Dose-dependent genomic DNA hypermethylation and mitochondrial DNA damage in Japanese tree frogs sampled in the Fukushima Daiichi area. J. Environ. Radioact.

Goodman, J. 2019. Effects of chronic radiation exposure on Daphnia: from individuals to populations. PhD Thesis, University of Stirling.

Goodman, J., Copplestone, D., Laptev, G. V., Gashchak, S., Auld, S.K.J.R. 2019. Variation in chronic radiation exposure does not drive life history divergence among Daphnia populations across the Chernobyl Exclusion Zone. Ecol. Evol., 9, 2640-2650. https://doi.org/10.1002/ece3.4931

Hinton, T.G., Byrne, M.E., Webster, S., Beasley, J.C. 2015. Quantifying the spatial and temporal variation in dose from external exposure to radiation: a new tool for use on freeranging wildlife. J. Environ. Radioact., 145, 58-65.

https://doi.org/10.1016/j.jenvrad.2015.03.027

Hoeschen, C. 2018. EURAMED's vision on medical radiation protection (research). Annals of the ICRP, 47, 152-158. https://doi.org/10.1177/0146645318759621

Holmstrup, M., Bindesbøl, A-M., Oostingh, G.J., Duschl, A., Scheil, V., Köhler, H-R., Loureiro, S., Soares, A.M.V.M., Ferreira, A.L.G., Kienle, C., Gerhardt, A., Laskowski, R., Kramarz, P.E., Bayley, M., Svendsen, C., Spurgeon, D.J. 2010. Interactions between effects of environmental chemicals and natural stressors: A review. Sci. Tot. Environ., 408, 37463762. https://www.sciencedirect.com/science/article/pii/S0048969709010493?via\%3Dihub

Horemans, N., Nauts, R., Vives i Batlle, J., Van Hees, M., Jacobs, G., Voorspoels, S., Gaschak, S., Nanba, K., Saenen, E. 2018. Genome-wide DNA methylation changes in two Brassicaceae species sampled alongside a radiation gradient in Chernobyl and Fukushima. J. Environ. Radioact., 192, 405-416. https://doi.org/10.1016/j.jenvrad.2018.07.012

Horemans, N., Spurgeon, D.J., Lecomte-Pradines, C., Saenen, E., Bradshaw, C., Oughton, D., Rasnaca, I., Kamstra, J.H., Adam-Guillermin, C. 2019. Current evidence for a role of 
epigenetic mechanisms in response to ionizing radiation in an ecotoxicological context. Environ. Pollut., 251, 469-483. https://doi.org/10.1016/j.envpol.2019.04.125

Hiyama, A., Nohara, C., Kinjo, S., Taira, W., Gima, S., Tanahara, A., Otaki, J.M. 2012. The biological impacts of the Fukushima nuclear accident on the pale grass blue butterfly. Sci. Rep., 2, 570. https://doi.org/10.1038/srep00570

International Atomic Energy Agency (IAEA). 2014. Handbook of parameter values for the prediction of radionuclide transfer to wildlife. Technical Reports Series No. 479. IAEA, Vienna. http://www-pub.iaea.org/MTCD/Publications/PDF/Trs479_web.pdf

International Commission on Radiological Protection (ICRP). 2007. The 2007 recommendations of the International Commission on Radiological Protection. ICRP Publication 103. Ann. ICRP, 37, 2-4. http://journals.sagepub.com/doi/pdf/10.1177/ANIB_37_2-4

International Commission on Radiological Protection (ICRP). 2009. Environmental protection - the concept and use of Reference Animals and Plants. ICRP Publication 108. Ann. ICRP, 38, 4-6. http://www.icrp.org/publication.asp?id=ICRP\%20Publication\%20108

International Commission on Radiological Protection (ICRP). 2017. Areas of research to support the system of radiological protection. ICRP ref 4832-9526-9446.

http://www.icrp.org/docs/ICRP\%20Research\%20Priorities\%202017.pdf Accessed $15 / 07 / 2019$

Jagoe, C.H., Dallas, C.E., Chesser, R.K., Smith, M.H., Lingenfelser, S.K., Lingenfelser, J.T., Holloman, K., Lomakin, M. 1998. Contamination near Chernobyl: radiocaesium, lead and mercury in fish and sediment radiocaesium from waters within the $10 \mathrm{~km}$ zone.

Ecotoxicology, 7, 201-209. https://doi.org/10.1023/A:1008934710904

Lerebours, A., Gudkov, D., Nagorskaya, L., Kaglyan, A., Rizewski, V., Leshchenko, A., Bailey, E.H., Bakir, A., Ovsyanikova, S., Laptev, G., Smith, J.T. 2018. Impact of environmental radiation on the health and reproductive status of fish from Chernobyl. Environ. Sci. Technol., 52, 16, 9442-9450. https://doi.org/10.1021/acs.est.8b02378

Lehmann, P., Boratyński, Z., Mappes, T., Mousseau, T.A., Møller, A.P. 2016. Fitness costs of increased cataract frequency and cumulative radiation dose in natural mammalian populations from Chernobyl. Sci. Rep., 6, 19974. https://www.nature.com/articles/srep19974

Liu X-M., Zhang, H. 2015. The effects of bacterial volatile emissions on plant abiotic stress tolerance. Front. Plant Sci., 6:774. https://doi.org/10.3389/fpls.2015.00774

Liu, Z., D. Guan, D., Crawford-Brown, D., Zhang, Q., He, K., Liu, J. 2013. A low-carbon road map for China. Nature, 500, 143. https://doi.org/10.1038/500143a

Mappes, T., Boratyński, Z., Kivisaari, K., Lavrinienko, A., Milinevsky, G., Mousseau, T.A., Møller, A.P., Tukalenko, E., Watts, P.C. 2019. Ecological mechanisms can modify radiation effects in a key forest mammal of Chernobyl. Ecosphere, 10, e02667.

https://doi.org/10.1002/ecs2.2667

Meredith, R.C.K., Mondon, K.J., Sherlock, J.C. 1988. A rapid method for the In vivo monitoring of radiocaesium activity in sheep. J. Environ. Radioact., 7, 209-214. https://doi.org/10.1016/0265-931X(88)90028-8

Møller, A.P., Mousseau, T.A. 2009. Reduced abundance of insects and spiders linked to radiation at Chernobyl 20 years after the accident. Biol. Let., 5, 356-359.

https://dx.doi.org/10.1098\%2Frsbl.2008.0778 
Møller, A P., Mousseau, T.A. 2013. Assessing effects of radiation on abundance of mammals and predator-prey interactions in Chernobyl using tracks in the snow. Ecol. Indic., 26, 112116. https://doi.org/10.1016/j.ecolind.2012.10.025

Møller, A.P., Mousseau, T.A. 2016. Are organisms adapting to ionizing radiation at Chernobyl? Trends Ecol. Evol., 31, 281-289. https://doi.org/10.1016/j.tree.2016.01.005

Møller, A P., Mousseau, T.A. 2018. Reduced colonization by soil invertebrates to irradiated decomposing wood in Chernobyl. Sci. Tot. Environ., 645, 773-779.

https://doi.org/10.1016/j.scitotenv.2018.07.195

Morelli, F., Benedetti, Y., Mousseau, T.A., Møller, A.P. 2018. Ionizing radiation and taxonomic, functional and evolutionary diversity of bird communities. J. Environ. Manage., 220, 183-190. https://doi.org/10.1016/j.jenvman.2018.05.032

Moss, R., Horrill, A.D. 1996. Metabolism of radiocaesium in red grouse. J. Environ. Radioact., 33, 49-62, https://doi.org/10.1016/0265-931X(95)00072-I

Mousseau, T.A., Møller, A.P. 2011. Landscape portrait: A look at the impacts of radioactive contaminants on Chernobyl's wildlife. Bull. At. Sci., 67, 38-46.

https://doi.org/10.1177/0096340211399747

Muikku, M., Beresford, N.A., Garnier-Leplace, J., Real, A., Sirkka, L., Thorne, M., Vandenhove, H., Willrodt, C. 2018. Sustainability and integration of radioecology-position paper. J. Radiol. Prot., 38, 152-163. https://doi.org/10.1088/1361-6498/aa9c0b

Murphy, J., Nagorskaya, L., Smith, J. 2011. Abundance and diversity of aquatic macroinvertebrate communities in lakes exposed to Chernobyl-derived ionising radiation. J. Environ. Radioact., 102, 688-694. https://doi.org/10.1016/j.jenvrad.2011.04.007

National Report of Ukraine. 2011. Twenty-five years after Chornobyl accident: Safety for the future. K.: KIM. ISBN 978-966-1547-64-2.

http://www.inaco.co.jp/isaac/shiryo/genpatsu/chornobyl25eng.pdf Accessed 15/07/2019

Newbold, L., Robinson, A., Rasnaca, I., Lahive, E., Gweon, H., Emmanuel, L., Oughton, D., Gashchak, S., Spurgeon, D., Beresford, N.A. Submitted. Genetic, epigenetic and microbiome characterisation of an earthworm species (Octolasion lacteum) along a radiation exposure gradient at Chernobyl. Environ. Pollut.

Parisot, F., Bourdineaud, J.P., Plaire, D., Adam-Guillermin, C., Alonzo, F. 2015. DNA alterations and effects on growth and reproduction in Daphnia magna during chronic exposure to gamma radiation over three successive generations. Aquat. Toxicol., 163, 27-36. https://doi.org/10.1016/j.aquatox.2015.03.002

Pentreath, R.J. 2009, Environment, pollution and human health: radioactivity. NERC report. https://nerc.ukri.org/research/funded/programmes/rate/report-pentreath/

Raines, K., 2018. The effect of chronic low-dose radiation on bumblebees. PhD Thesis, University of Stirling.

Salomaa, S. 2016. Synergies between the medical SRA and the SRAs of MELODI and EURADOS. D2.7. EJP-CONCERT European Joint Programme for the Integration of Radiation Protection Research (H2020 - 662287). http://www.concerth2020.eu/Document.ashx?dt=webandfile=/Lists/Deliverables/Attachments/26/D13_CONCE RT\%20D2_7\%20Synergies\%20between\%20Medical_MELODI_EURADOS_appoved.pdfan dguid=01b5ac77-b2ec-4cda-9c98-917dba396f0f Accessed 15/07/2019. 
Sharov, P., Dowling, R., Gogishvili, M., Jones, B., Caravanos, J., McCartor, A., Kashdan Z., Fuller, R. 2016. The prevalence of toxic hotspots in former Soviet countries. Environ. Pollut., 211, 346-353. https://doi.org/10.1016/j.envpol.2016.01.019

Smith, J. 2019. Field evidence of significant effects of radiation on wildlife at chronic low dose rates is weak and often misleading. A comment on "Is non-human species radiosensitivity in the lab a good indicator of that in the field? Making the comparison more robust" by Beaugelin-Seiller et al.". J. Environ. Radioact., 105895.

https://doi.org/10.1016/j.jenvrad.2019.01.007

Søvik, A., Vivies i Batlle, J., Duffa, C., Masque, P., Lind, O.C., Salbu, B., Kashparov, V., Garcia-Tenorio, R., Beresford, N.A., Thørring, H., Skipperud, L., Michalik, B., Steiner, M. 2017. Final report of COMET WP3 activities. COMET D-N³.7. Contract No. 604974. https://radioecologyexchange.org/sites/default/files/files/COMET\%20Deliverable\%20D3_7\%20WP3\%20Final\% 20report_PU\%20version.pdf Accessed 15/07/2019.

Steiner, M., Willrodt, C., Wichterey, K., Ikäheimonen, T., Ioshchenko, V., Hutri, K-L., Muikku, M., Outola, I., Beresford, N.A., Bradshaw, C., Dowdall, M., Eyrolle-Boyer, F., Guillevic, J., Hinton, T., Howard, B.J., Liland, A., Michalik, B., Mora, J.C., Oughton, D., Real, A., Robles, B., Salbu, B., Stark, K., Sweeck, L. 2013. Observatories for radioecological research - Description. STAR D-N².3. Contract No. Fission-2010-3.5.1-269672. https://radioecology-exchange.org/sites/default/files/STAR_Deliverable-2.3.pdf Accessed $\underline{15 / 07 / 2019}$

Thackeray, S.J., Henrys, P.A., Hemming, D., Bell, J.R., Botham, M.S., Burthe, S., Helaouet, P., Johns, D.G., Jones, I. D., Leech, D.I., Mackay, E.B., Massimino, D., Atkinson, S., Bacon, P.J., Brereton, T.M., Carvalho, L., Clutton-Brock, T.H., Duck, C., Edwards, M., Elliott, J.M., Hall, S.J.G., Harrington, R., Pearce-Higgins, J.W., Høye, T.T., Kruuk, L.E.B., Pemberton, J.M., Sparks, T.H., Thompson, P.M.. White, I., Winfield, I.J., Wanless, S. 2016. Phenological sensitivity to climate across taxa and trophic levels. Nature, 535, 241-245. https://www.nature.com/articles/nature18608

Thorne, M.C. 2018. Radioecology in Europe. J. Radiol. Prot., 38, E5-E9. https://doi.org/10.1088/1361-6498/aa9c0f

Volkova, P.Y., Geras'kin, S.A., Horemans, N., Makarenko, E.S., Saenen, E., Duarte, G.T., Nauts, R., Bondarenko, V.S., Jacobs, G., Voorspoels, S., Kudin, M. 2018. Chronic radiation exposure as an ecological factor: Hypermethylation and genetic differentiation in irradiated Scots pine populations. Environ. Pollut., 232, 105-112.

https://doi.org/10.1016/j.envpol.2017.08.123

van de Walle, J., Horemans, N., Saenen, E., Van Hees, M., Wannijn, J., Nauts, R., van Gompel, A., Vangronsveld, J., Vandenhove, H., Cuypers, A. 2016. Arabidopsis plants exposed to gamma radiation in two successive generations show a different oxidative stress response. J. Environ. Radioact., 165, 270-279. https://doi.org/10.1016/j.jenvrad.2016.10.014

Wood, M.D., Mothersill, C., Tsakanova, G., Cresswell, T., Woloschak, G.E. (Eds.). Submitted. Biomarkers of radiation in the environment. Springer Nature. https://group.springernature.com/gp/group Accessed 30/07/2019

World Nuclear Association. 2019. Plans for new reactors worldwide. http://www.worldnuclear.org/information-library/current-and-future-generation/plans-for-new-reactorsworldwide.aspx Accessed 15/07/2019 